A RCHIWA，BIBLIOTEKI

I MUZEA KOŚCIELNE 113 (2020)

https://doi.org/10.31743/abmk.10025

JOLANTA WASILEWSKA* - LUBLIN

ANDRZEJ SZPONAR** - LUBLIN

\title{
MERRY CHRISTMAS \\ - WYSTAWA W BIBLIOTECE UNIWERSYTECKIEJ KUL. 18 GRUDNIA 2019 - 2 LUTEGO 2020
}

Latem 2019 roku Henryk Wójcik, lublinianin, były student Historii Sztuki KUL, odwiedził Bibliotekę Uniwersytecką KUL. Na spotkaniu z dr Katarzyną Kołakowską dyrektor BU KUL zaproponował, ze przekaże księgozbiór o tematyce bożonarodzeniowej, gromadzony przez wiele lat. Uzgodnili, że kiedy książki dotrą do Biblioteki, zostaną zaprezentowane pracownikom i czytelnikom na wystawie. Tworzeniem wystawy zajęli się: Jolanta Wasilewska - kustosz wystawy, Andrzej Szponar - współorganizator, Kamila Mucha - porządkowanie tematyczne książek i Marek Popielnicki - opracowanie komputerowe katalogu, zaproszenia i plakatu. Wszystkie książki zostały opracowane bibliograficznie i umieszczone w wydrukowanym katalogu. Dodatkowo wystawę książek urozmaiciło 130 świątecznych kart pocztowych - prywatny zbiór H. Wójcika. Wernisaż wystawy pt.: Merry Christmas odbył się 18 grudnia 2019 roku. Licznie zgromadzonych gości przywitała dyrektor BU KUL dr K. Kołakowska, następnie o ekspozycji opowiedziała kustosz wystawy J. Wasilewska, która wspomniała, że kolekcja książek i pocztówek w języku angielskim z końca XIX i początku XX wieku, w większości druków kanadyjskich i amerykańskich, jest własnością H. Wójcika, lublinianina mieszkającego w kanadyjskim Toronto. Urozmaiceniem wystawy byli wyjątkowi goście, którzy podzielili się swoimi refleksjami o przeżywaniu Bożego Narodzenia w swoich krajach.

Ks. dr hab. Sławomir Zych z Ośrodka Badań nad Polonią i Duszpasterstwem Polonijnym w krótkiej prelekcji przedstawił historię Bożego Narodzenia. Wspo-

* Jolanta Wasilewska - mgr historii sztuki; starszy kustosz dyplomowany w Bibliotece Uniwersyteckiej Katolickiego Uniwersytetu Lubelskiego Jana Pawła II; e-mail: jolanta.wasilewska@kul.pl https://orcid.org/0000-0003-0892-2766

** Andrzej Szponar - lic.; kierownik Działu Obsługi w Bibliotece Uniwersyteckiej Katolickiego Uniwersytetu Lubelskiego Jana Pawła II; e-mail: szponarandrzej@kul.pl

https://orcid.org/0000-0002-5616-4579 
mniał, że powstanie święta Narodzenia Jezusa należy do największych zagadek początku chrześcijaństwa i historii liturgii. Opowiedział, że w przeszłości terminy obchodów świąt były różne, świętowano w styczniu, marcu, kwietniu, a nawet w maju. Ostatecznie wybrano datę 25 grudnia - dzień przesilenia zimowego. Informacja o celebracji Narodzenia Chrystusa 25 grudnia po raz pierwszy została zamieszczona w rzymskim kalendarzu, któremu historycy nadali nazwę Chronograf z 354 roku.

Tradycja świąteczna oczami dziecka została ukazana w wierszu napisanym specjalnie na tę okazję przez Kacpra Szponara, jedenastoletniego ucznia Szkoły Podstawowej $\mathrm{nr} 7 \mathrm{im}$. ks. Jana Twardowskiego w Lublinie.

\section{Zima}

Kiedy drzewa usypiaja, gwiazdy betlejemskie rozkwitaja

Ludzie na gwiazdkę czekaja

Cztery razy przed kościołem się stawiaja,

Kiedy śnieg prószy, lub jak kto woli spamuje,

Do domostw zjeżḋaja się ciocie $i$ wuje,

Ja czekam i czekam, popijajac szklanke mleka,

Czekam na tę piękna Wigilię, na spotkanie z dziadkami,

I obdarowywanie się prezentami

Kiedy już pojawią się wszyscy goście, wypatrujemy pierwszej gwiazdki na niebie, a kiedy już ją zobaczymy, to głośno oznajmiamy dorosłym, że już nadszedł czas rozpocząć wigilijną kolację. Najpierw łamiemy się opłatkiem, składamy sobie życzenia, a czasami u babci lub dziadka się pojawia łza. Zaciekawieni zapachem próbujemy wszystkich potraw, choć odrobinkę, ale uwaga - jest jeszcze wolne miejsce przy stole, a na nim talerz. Dla kogo? Dla wszystkich potrzebujących, strapionych i samotnych, by mogli radośnie przeżyć szczególny wieczór poprzedzający święta Bożego Narodzenia.Aż w końcu nadchodzi czas, aby wstać od stołu i sprawdzić, czy święty Mikołaj w tym roku pod choinką zostawił prezenty. A na koniec sprawdzamy, czy nasi domowi pupile, czyli zwierzęta, przemówią do nas ludzkim głosem. Nawet jeśli nie, to nic nie szkodzi, bo przed nami ostatnie ważne zadanie. O północy wybieramy się na uroczystą mszę, która się nazywa Pasterka; kiedy wracamy do domu, nawet spać się nie chce, bo dobrze by było prezentami się jeszcze nacieszyć.

O zwyczajach świątecznych w swoich krajach opowiadali zaproszeni zagraniczni goście. Jyun-Yz Deng z Tajwanu - wykładowca na Wydziale Politologii UMCS, opowiedział, że na tej chińskiej wsypie jest to zwykły dzień, chociaż Tajwańczycy chętnie przejmują zwyczaje świąteczne od chrześcijan. Okres świąteczny traktują jako okazję do radości i dobrej zabawy w gronie znajomych i przyjaciół. Dekorują ozdobami swoje domy, sklepy i inne lokale. Spotykają się w restauracjach na specjalnie organizowanych świątecznych kolacjach. Słuchają kolęd w języku chińskim i angielskim. Dużo czasu spędzają na kupowaniu prezentów. W większych miastach organizowane są bożonarodzeniowe kiermasze, wesołe miasteczka i lodowiska. Wielką atrakcją dla mieszkańców jest sztuczny śnieg.

$\mathrm{Na}$ Białorusi święta obchodzone są w zależności od regionu i rodziny. Na Grodzieńszczyźnie zwyczaje świąteczne są bardzo podobne jak w Polsce - stwierdziła 
Karalina Kaspiarovich, studentka Filologii Polskiej KUL. Wieczerza wigilijna jest skromna i składa się głównie z postnych dań, nie ma barszczu ani karpia, są za to pierożki z grzybami, racuchy z cukrem, obwarzanki z makiem i kisiel robiony $\mathrm{z}$ kompotu $\mathrm{z}$ wiśni. Ważną potrawą jest kutia - owsianka ze zbóż, głównie z jęczmienia z miodem i makiem; wspólne spożywanie tej potrawy symbolizuje dobrobyt, dobrą wolę oraz pojednanie między członkami rodziny. Ciekawym zwyczajem na wsi w nocy z 24 na 25 grudnia jest wyjmowanie bram z płotów i ogrodzeń wokół domów, a dzieci i młodzież w strojach ludowych z Gwiazdą Betlejemską chodzą od domu do domu, kolędując i obwieszczając ludziom radość Bożego Narodzenia.

Margarita Chekhovskaia, pochodząca z Syberii studentka Wydziału Nauk Społecznych i Stosunków Międzynarodowych KUL, opowiedziała o tradycji i zwyczajach świąt u prawosławnych. Zgodnie z kalendarzem juliańskim Boże Narodzenie poprzedzone jest 40-dniowym postem zwanym Filipowym. Prawosławni zbierają się w gronie rodzinnym 7 stycznia u najstarszego członka rodziny, zazwyczaj u babci, która według starych tradycji przygotowuje świąteczny stół zasłany białym haftowanym obrusem oraz ustawia woskowe świece w kubku wypełnionym zbożem. Przy stole wigilijnym musi być parzysta liczba gości - jeśli wypada nieparzysta, dostawia się pusty talerz. Posiłek wigilijny rozpoczyna się od dzielenia prosforą, czyli przaśnym chlebem. Na talerz kładzie się sianko, na którym stawiana jest misa $\mathrm{z}$ kutią. Zgodnie z tradycją na świątecznym stole powinny znaleźć się: chleb jako znak pożywienia, sól jako symbol dostatku, czosnek jako oznaka zdrowia oraz miód oznaczający powodzenie. Po wieczerzy śpiewane są koladki, prawosławne kolędy.

Na wystawie Merry Christmas znalazło się ponad 300 książek i 130 kart pocztowych. Tematyka druków jest wprawdzie bożonarodzeniowa, jednak zobaczyć tam było można różności - od książeczek dla dzieci o Santa Clausie, poprzez bajki i legendy o świętach, aż po opracowania historyczne. Najciekawszym fragmentem wystawy były autentyczne karty świąteczne, które kiedyś były wysłane z życzeniami, zaadresowane i opłacone znaczkami pocztowymi. Tylko kilkanaście kart miało tematykę religijną, na pozostałych znajdowały się kwiaty, pejzaże, dzieci i zwierzęta. Niektóre karty świąteczne były zaskakujące - np. karta z wizerunkiem kota w czepku kąpielowym czy konia w stajni. Ciekawe były też różne kształty kart - np. w formie dmuchawy do rozpalania ognia, karty z frędzelkami czy ażurowe. Kolekcja prezentowana na wystawie wspaniale ilustrowała tradycje Świąt Bożego Narodzenia obchodzonych w Ameryce Północnej.

Dzięki sponsorom: bibliofilowi H. Wójckowi z Toronto i ks. Jerzemu Latawcowi (niegdyś wicedyrektorowi BU KUL, a dziś proboszczowi w Czemiernikach) udało się wydrukować barwny katalog druków z wystawy. 


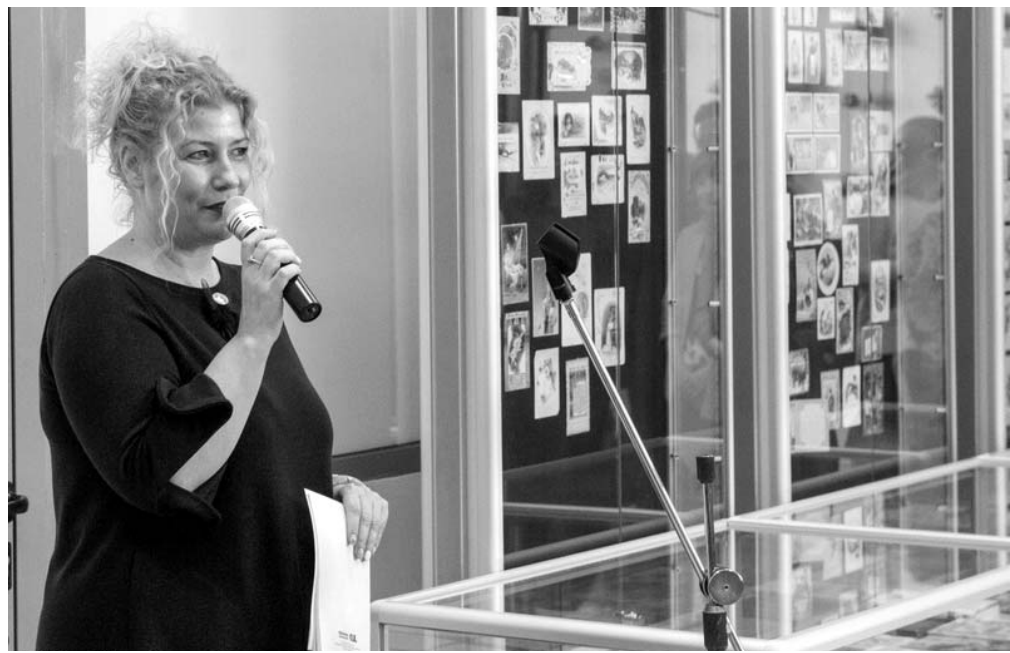

I1.1. Dyrektor Biblioteki KUL dr Katarzyna Kołakowska.

(Fot. S. Stasz)

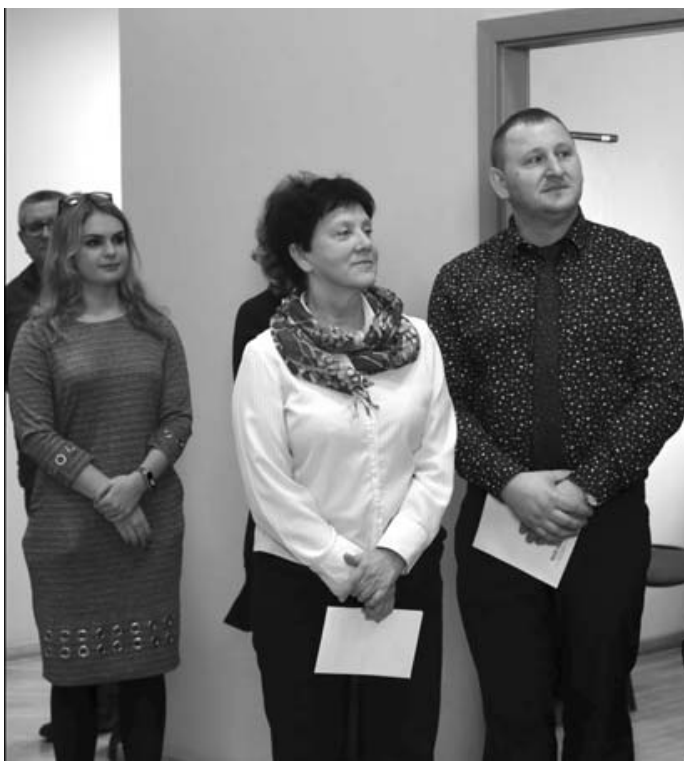

I1.2. Twórcy wystawy Kamila Mucha, Jolanta Wasilewska, Andrzej Szponar. (Fot. S. Stasz) 


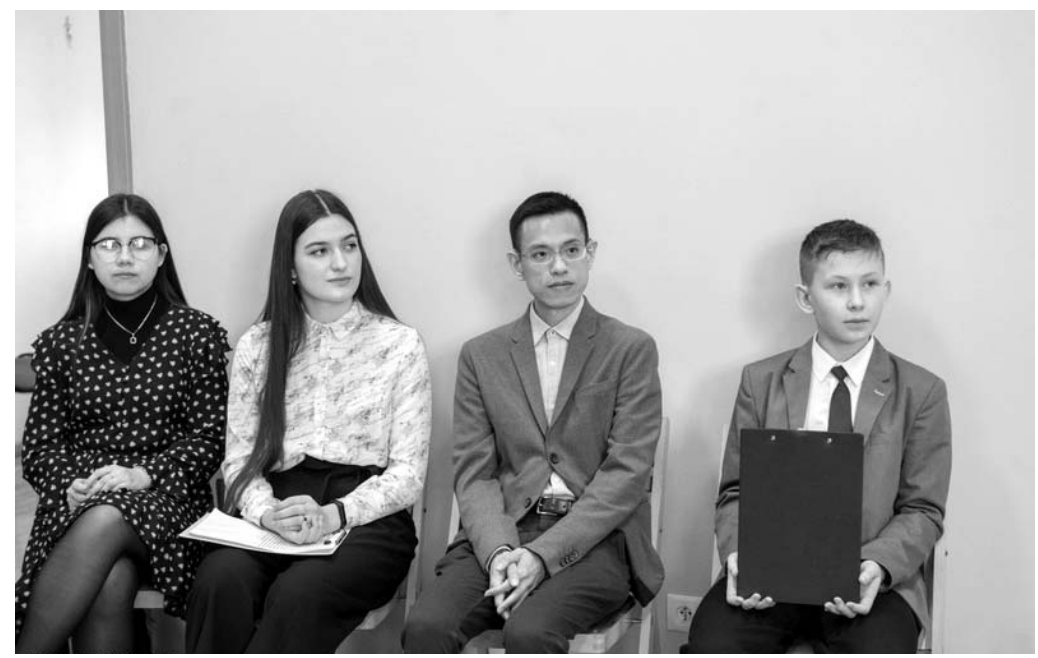

Il.3. Prelegenci: Margarita Chekhovskaia, Karalina Kaspiarovich, Jyun-Yz Deng, Kacper Szponar.

(Fot. T. Koryszko)

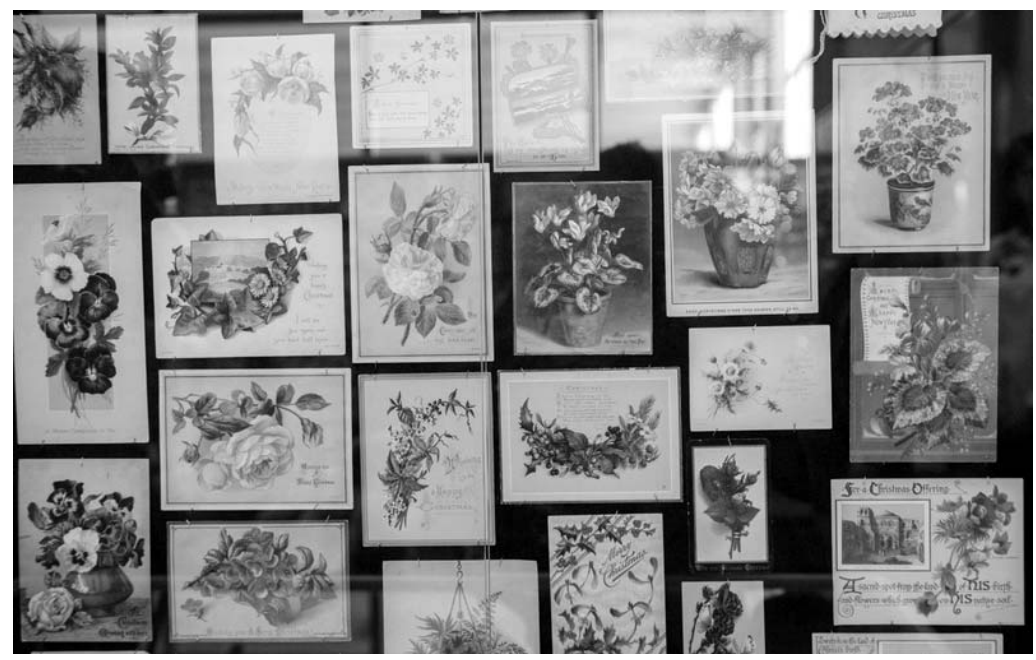

I1.4. Karty świąteczne.

(Fot. T. Koryszko) 


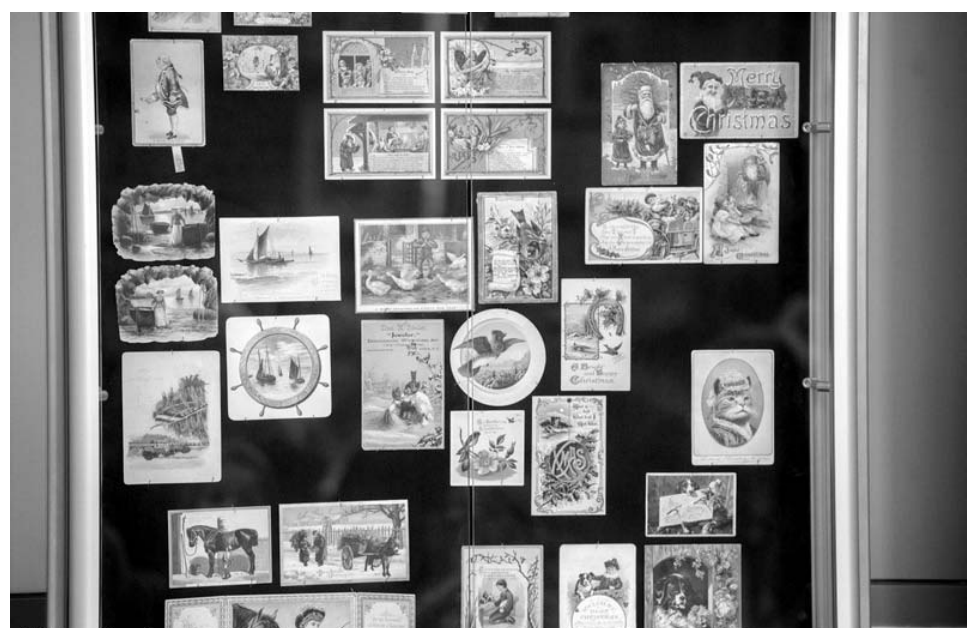

Il.5. Karty świąteczne.

(Fot. T. Koryszko)

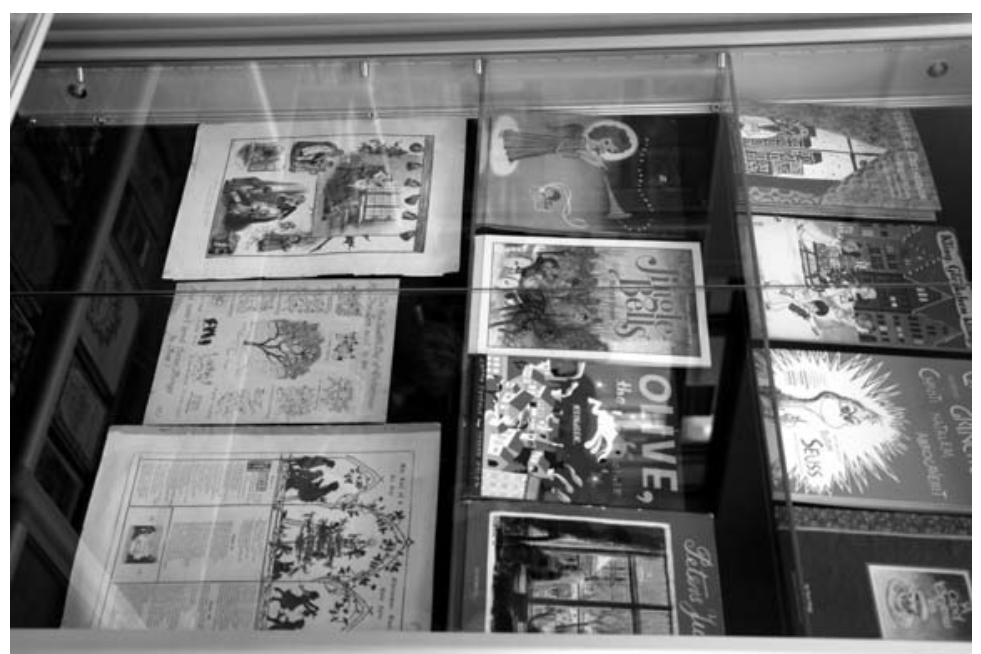

Il.6. Książki w gablotach.

(Fot. T. Koryszko). 